\title{
A Mechanism for the Direct Regulation of T-Type Calcium Channels by $\mathrm{Ca}^{2+} /$ Calmodulin-Dependent Kinase II
}

\author{
Philip J. Welsby, ${ }^{1 \star}$ Hongge Wang, ${ }^{1 *}$ Joshua T. Wolfe, ${ }^{1}$ Roger J. Colbran, ${ }^{2}$ Michael L. Johnson, ${ }^{1}$ and Paula Q. Barrett ${ }^{1}$ \\ ${ }^{1}$ Department of Pharmacology, University of Virginia, Charlottesville, Virginia 22908, and ${ }^{2}$ Department of Molecular Physiology and Biophysics, Vanderbilt \\ University, Nashville, Tennessee 37232
}

Low-voltage-activated (LVA) $\mathrm{Ca}^{2+}$ channels are widely distributed throughout the CNS and are important determinants of neuronal excitability, initiating dendritic and somatic $\mathrm{Ca}^{2+}$ spikes that trigger and shape the pattern of action potential firing. Here, we define a molecular mechanism underlying the dynamic regulation of $\alpha_{1 \mathrm{H}}$ channels $\left(\mathrm{Ca}_{\mathrm{v}} 3.2\right)$, by $\mathrm{Ca}^{2+} / \mathrm{CaM}$-dependent protein kinase II (CaMKII). We show that channel regulation is selective for the LVA $\alpha_{1 \mathrm{H}} \mathrm{Ca}^{2+}$ channel subtype, depends on determinants in the $\alpha_{1 \mathrm{H}}$ II-III intracellular loop, and requires the phosphorylation of a serine residue absent from unregulated $\alpha_{1 \mathrm{G}}\left(\mathrm{Ca}_{\mathrm{v}} 3.1\right)$ channels. These studies identify the $\alpha_{1 \mathrm{H}}$ channel as a new substrate for CaMKII and provide the first molecular mechanism for the direct regulation of T-type $\mathrm{Ca}^{2+} \mathrm{channels}$ by a protein kinase. Our data suggest a novel mechanism for modulating the integrative properties of neurons.

Key words: calcium [Ca]; calmodulin; channel; dendrite; hippocampus; protein kinase; T-type

\section{Introduction}

Low-voltage-activated (LVA), T-type, $\mathrm{Ca}^{2+}$ channels are important determinants of neuronal excitability (McCormick, 1992; Huguenard, 1996; Eilers and Konnerth, 1997; Hausser et al., 2000). They support the forward propagation of distal dendritic inputs in neocortical (Markram and Sakmann, 1994) and CA1 hippocampal pyramidal neurons (Magee and Johnston, 1995a,b) and mediate low-threshold spikes that support somatic burst firing in thalamocortical (Huguenard and McCormick, 1992; Destexhe et al., 1996) and CA3 hippocampal pyramidal neurons (Fisher et al., 1990; Migliore and Shepherd, 2002). Both dendritic boosting and neuronal bursting supported by LVA channels amplify subthreshold stimuli (Hausser et al., 2000). LVA Ca ${ }^{2+}$ channels can also facilitate long-term changes in neuronal plasticity as demonstrated in the dorsal horn (Ikeda et al., 2003) and CA1 pyramidal neurons (Su et al., 2002). Thus, LVA Ca ${ }^{2+}$ channel activity can contribute to the complex and diverse firing behavior of neurons.

LVA Ca ${ }^{2+}$ channels belong to the $\mathrm{Ca}_{\mathrm{v}} 3$ family, of which there are three family members $\left(\mathrm{Ca}_{\mathrm{v}} 3.1, \mathrm{Ca}_{\mathrm{v}} 3.2\right.$, and $\mathrm{Ca}_{\mathrm{v}} 3.3: \alpha_{1 \mathrm{G}}, \alpha_{1 \mathrm{H}}$, and $\alpha_{1 \mathrm{II}}$ ) (Cribbs et al., 1998; Perez-Reyes et al., 1998; Lee et al., 1999). Little is known about the regulation of this $\mathrm{Ca}^{2+}$ channel class, in contrast to high voltage-activated $\mathrm{Ca}^{2+}$ channels that are well-established targets of G-proteins and kinases (Catterall, 2000). One defined mode of LVA channel regulation depends on the activity of $\mathrm{Ca}^{2+} / \mathrm{CaM}$-dependent protein kinase II (CaMKII), an important regulator of ion channel activity (Soderling and Derkach, 2000; Hudmon and Schulman, 2002). Our previous

\footnotetext{
Received July 10, 2003; revised Sept. 15, 2003; accepted Sept. 15, 2003.

This study was supported by National Institutes of Health-National Heart, Lung, and Blood Institute Grant R01 36977 (P.Q.B.). J.T.W. was supported by predoctoral fellowships from the University of Virginia Cardiovascular Research Center and the American Heart Association (Mid-Atlantic Affiliate). We thank E. Perez-Reyes for $\alpha_{1 \mathrm{H}}$ and $\alpha_{1 G}$ clones and D. Bayliss, J. J. Zhu, and E. M. Talley for their careful reading of this manuscript.

P.J.W. and H.W. contributed equally to this work.

Correspondence should be addressed to Paula Q. Barrett at the above address. E-mail: pqb4b@virginia.edu. Copyright $\odot 2003$ Society for Neuroscience $\quad$ 0270-6474/03/2310116-06\$15.00/0
}

work established that CaMKII modulates $\alpha_{1 \mathrm{H}}$ but not $\alpha_{1 \mathrm{G}}$ channel gating, preferentially increasing current at subthreshold potentials (Wolfe et al., 2002). Because the activity of multimeric CaMKII depends on $\mathrm{Ca}^{2+} / \mathrm{CaM}$ binding and intersubunit autophosphorylation, CaMKII activity can extend beyond the lifetime of the $\mathrm{Ca}^{2+}$ signal and enable the kinase to sum and thereby respond to small repeated $\mathrm{Ca}^{2+}$ transients (Soderling and Derkach, 2000; Hudmon and Schulman, 2002). Thus, CaMKIIdependent regulation of LVA channel activity could persist during weak synaptic stimulation.

CaMKII is ubiquitously distributed throughout the CNS and PNS and is a major constituent of postsynaptic densities of excitatory synapses (Kennedy et al., 1983; Kelly et al., 1984; Braun and Schulman, 1995; Liu and Jones, 1996; Hudmon and Schulman, 2002). The widespread localization of this kinase (Braun and Schulman, 1995) and LVA channels (Perez-Reyes, 2003) in both dendritic and somatic compartments (Liu and Jones, 1996; Shen et al., 1998; Thiagarajan et al., 2002) and their independent roles in modulating synaptic transmission suggested a direct mechanism for the regulation of $\alpha_{1 \mathrm{H}}$ channels by CaMKII that would be of general importance to neuronal function.

Here, we show that the regulation of $\alpha_{1 \mathrm{H}}$ channels by CaMKII depends on structural determinants contained within the intracellular linker connecting channel domains II and III. A serine residue ( $\mathrm{Ser}^{1198}$ ) in the $\mathrm{H}_{\mathrm{II}-\mathrm{III}}$ linker is a preferred CaMKII phosphorylation site and is critical to this modulation. These data identify the $\alpha_{1 \mathrm{H}} \mathrm{Ca}^{2+}$ channel as a direct effector for CaMKII and provide a new CaMKII-dependent mechanism for enhancing neuronal excitability.

\section{Materials and Methods}

Preparation of human $\alpha_{1 G}$ and $\alpha_{1 H}$ chimeric and mutant constructs. All constructs were prepared using a PCR-subcloning strategy in which PCR products were verified by DNA sequencing. A truncated $\alpha_{1 \mathrm{H}}$ sequence (AF051946 version 1.0) was extended by PCR to add a sequence encoding for 
50 amino acids using 5'-GACAGCCCTAGGGACAC-3' [5'-CGAGAATGCACTCGAGCTACACGGGGTCATC-3' (AF051946 modified)]. The II-III linker regions were amplified from $\alpha_{1 \mathrm{H}}$ (AF051946 modified) and $\alpha_{1 \mathrm{G}}$ (AF190860) (Cribbs et al., 2000) were generated by PCR $\left(\alpha_{1 \mathrm{H}}, 5^{\prime}\right.$-TCCTGTACAACGGCATGG- $3^{\prime}$ and $5^{\prime}$-CTCTCTAGATATCAGCGTCTCCACC$3^{\prime} ; \alpha_{1 \mathrm{G}}, 5^{\prime}$-CCTGTACAATGGTATGGCCTCC-3' and 5'-CTCTCTAGACACGTGGTCGAACATCTTG-3') and subcloned into pUC18 at the SmaI$\mathrm{XbaI}$ site, resulting in pUC18- $\mathrm{H}_{\mathrm{II}-\mathrm{III}}$ and $\mathrm{pUC18}-\mathrm{G}_{\mathrm{II}-\mathrm{III}}$. The PCR reaction introduced an upstream $B s r$ GI site in the $\mathrm{H}_{\mathrm{II}-\mathrm{III}}$. The II-III linker of $\alpha_{1 \mathrm{G}}$ was isolated from pUC18- $\mathrm{G}_{\mathrm{II}-\mathrm{III}}$ by BsrGI-PmlI digestion and inserted into pUC18- $\mathrm{H}_{\mathrm{II}-\mathrm{III}}$ at the corresponding site to replace $\mathrm{H}_{\mathrm{II}-\mathrm{III}}$, resulting in pUC18-G $\mathrm{G}_{\mathrm{II}-\mathrm{III}}-1$. Finally, the BsrGI-EcoRV fragment containing the II-III linker of $\alpha_{1 \mathrm{G}}$ was isolated from the last construct and subcloned back to pcDNA3 $-\alpha_{1 \mathrm{H}}$, resulting in construct $\mathrm{H}-\mathrm{G}_{\mathrm{II}-\mathrm{III}}$. Similarly, preparation of the construct $\mathrm{G}-\mathrm{H}_{\mathrm{II}-\mathrm{III}}$ involved an intermediate construct pUC18- $\mathrm{H}_{\mathrm{II}-\mathrm{III}}-1$ that was generated by subcloning a PCR (5' -CCAATGCATCTTTTCGGCTGCAAGTTC- ${ }^{\prime}$ and $5^{\prime}$-CCATCTAGACACGTGATCAAACATCTTG-3') product of $\mathrm{H}_{\mathrm{II}-\mathrm{III}}$ into $\mathrm{pUC18}$ at the SmaI-XbaI site, in which an NsiI site was introduced upstream of $\mathrm{H}_{\text {II-III }}$. The $\mathrm{H}_{\text {II-III }}$ linker was isolated from an NsiIPmlI digestion of pUC18- $\mathrm{H}_{\mathrm{II}-\mathrm{III}}-1$ and subcloned into $\mathrm{pUC18}-\alpha_{1 \mathrm{G}}$ replacing the original II-III linker, resulting in pUC18-G-H $\mathrm{H}_{\mathrm{II}-\mathrm{III}}$. The chimearic channel was subcloned into pcDNA3.1 (-) at the EcoRI-KpnI site, resulting in the construct $\mathrm{G}-\mathrm{H}_{\mathrm{II}-\mathrm{III}}$. All mutations were introduced into the intermediate constructs pUC18- $\mathrm{H}_{\mathrm{II}-\mathrm{III}}$ or pUC18- $\mathrm{H}_{\mathrm{II}-\mathrm{III}}{ }^{-1}$ using QuikChange XL SiteDirected Mutagenesis Kit (catalog \#200517; Stratagene, La Jolla, CA). Last, the construct $\mathrm{G}-\mathrm{H}_{\mathrm{C}}$ terminus was prepared by fusing the $5^{\prime}$ section of $\alpha_{1 \mathrm{H}}$ and the $3^{\prime}$ section of $\alpha_{1 \mathrm{G}}$ at the PmlI site in pcDNA3.

Preparation of glutathione S-transferase fusion proteins. The wild-type DNA construct of the glutathione $S$-transferase (GST)- $\mathrm{H}_{\text {II-III }}$ fusion protein was generated by subcloning a PCR (5'-CATGGATCCCAGGCGGAGGGCGATG- $3^{\prime}$ and $5^{\prime}$-CAAGATATCCGTGGGTCCAGGGACTC$\left.3^{\prime}\right)$ product of $\alpha_{1 \mathrm{H}}\left(\alpha_{1 \mathrm{H} 3117-3696}\right)$ into pGEX-2T at the BamHI-SmaI site. The mutations S1198A and/or S1153A were introduced by PCR. All PCR products were verified by DNA sequencing.

In vitro CaMKII $\gamma$ c phosphorylation. GST- $\mathrm{H}_{\mathrm{II}-\mathrm{III}}$ fusion proteins were purified from transformed Escherichia coli BL21 cell lysates by binding to $200 \mu \mathrm{l}$ of $50 \%(\mathrm{w} / \mathrm{v})$ slurry of glutathione-Sepharose 4B (Amersham Biosciences, Arlington Heights, IL). After repeated washes with PBS, the GST-H $_{\text {II-III }}$ fusion proteins were eluted from the beads with $20 \mathrm{~mm}$ reduced glutathione in a Tris- $\mathrm{HCl}$ buffer, $\mathrm{pH}$ 7.4. Purity of the isolated proteins was assessed by SDS-PAGE, and concentration was determined using a Coomassie Protein Assay (catalog \#1856209; Pierce, Rockford, IL). It was estimated from Coomassie staining of SDS-PAGE samples that $50 \%$ of the final protein was full length. Phosphorylation of the GST-H $\mathrm{H}_{\text {II- }}$ III fusion proteins was performed in a final volume of $50 \mu \mathrm{l}$ containing 1 $\mu \mathrm{M}$ fusion protein, $1 \mathrm{~mm}$ DTT, $10 \mathrm{~mm}$ HEPES, $0.5 \mathrm{~mm} \mathrm{CaCl}_{2}, 2 \mu \mathrm{M}$ calmodulin, $10 \mathrm{~mm} \mathrm{MgCl} 2,0.1 \%$ Triton X-100, $1 \mathrm{mg} / \mathrm{ml} \mathrm{BSA}$, and 100 $\mu \mathrm{M}\left[{ }^{32} \mathrm{P}\right]$ ATP $(10 \mathrm{mCi} / \mathrm{ml})$. Reaction was initiated by the addition of 30 nM purified recombinant porcine CaMKII $\gamma c$, and samples were incubated at $37^{\circ} \mathrm{C}$ for up to $15 \mathrm{~min}$. Reactions were terminated by addition of $20 \mu \mathrm{l}$ of $4 \times$ SDS sample buffer containing $500 \mathrm{~mm}$ EGTA, followed by incubation at $95^{\circ} \mathrm{C}$ for $5 \mathrm{~min}$ before separation by SDS-PAGE. Gels were Coomassie stained, and, after autoradiography, bands corresponding to phosphorylated GST-H $\mathrm{H}_{\mathrm{II}-\mathrm{III}}$ fusion proteins were cut from the gel, and radioactivity was assessed using liquid scintillation counting.

Electrophysiology. Whole-cell currents were recorded from adherent HEK293 cells using a standard patch electrode voltage-clamp method (Lu et al., 1994). To eliminate $\mathrm{K}^{+}$currents and fix free [calcium], we used internal solutions containing the following (in $\mathrm{mM}$ ): $115 \mathrm{CsCl}, 1$ tetrabutylammonium chloride, $1 \mathrm{MgCl}_{2}, 5 \mathrm{Mg}$-ATP, 1 Li-GTP, 20 HEPES, pH.7.2 (adjusted with $\mathrm{CsOH}$ ), and 11 BAPTA; added $\mathrm{CaCl}_{2}$ fixed the free $\mathrm{Ca}^{2+}$ at $27 \mathrm{~nm}(0.9 \mathrm{~mm})$ or $1 \mu \mathrm{M}(8.8 \mathrm{~mm})$ with $2 \mu \mathrm{M}$ CaM (Lu et al., 1994). HEK293 cells were superfused with a solution containing the following (in mM): $127 \mathrm{TEA}-\mathrm{Cl}, 10 \mathrm{CaCl}_{2}, 0.5 \mathrm{MgCl}_{2}, 10 \mathrm{HEPES}, 5$ dextrose, and 32 sucrose, $\mathrm{pH} 7.4$ (adjusted with $\mathrm{CsOH}$ ). Currents were filtered at $2.5 \mathrm{kHz}$ and sampled at $12.5 \mathrm{kHz}$; leak subtraction was performed on line using $\mathrm{P} / 4$ protocol. Activation gating was determined using tail currents in response to 15 test depolarizations in $5 \mathrm{mV}$ increments $(-60$ to +10 $\mathrm{mV} ; 10.4 \mathrm{msec}$ ) from a holding potential of $-90 \mathrm{mV}$ during repolariza- tion to $-60 \mathrm{mV}$ (45 msec). Interpulsing time was $6 \mathrm{sec}$ to allow for recovery from inactivation. Tail currents were fitted to a single exponential plus a constant using the Chebyshev algorithim in pClamp 6.0 software (Axon Instruments, Foster City, CA). As described previously (Wolfe et al., 2002), activation gating fitted significantly better to a Boltzmann distribution raised to the second power: $\left[I / I_{\max }=1 /(1+\right.$ $\left.\exp \left[\left(V_{0.25}-V_{t}\right) / k\right]\right)^{2}$, where $k$ is the slope factor (mV/e-fold change), $V_{t}$ is the test potential, and $I_{\max }$ is the maxium current. Half-activation potential was calculated as follows: $V_{0.5}=0.882(k)+V_{0.25}$. Data obtained with the CaMKII-activating internal solution were fitted to the sum of two Boltzmanns. Averaged data sets obtained with activating or non-activating solutions were analyzed concurrently to obtain a single set of parameters for the non-modulated component that optimally describes both sets of data and another set of parameters for the second modulated component. Parameter estimations were performed by a nonlinear leastsquares procedure (Johnson and Frasier, 1985) using boot strapping to determine confidence limits (Efron and Tibshirani, 1993). To evaluate the goodness-of-fit to a single versus a double Boltzmann distribution, the sum of the squared residuals was calculated and mapped into a probability by calculating a $Z$ score for the runs test (Straume and Johnson, 1992).

\section{Results}

Activation of CaMKII induces an $11 \mathrm{mV}$ hyperpolarizing shift in the half-activation potential $\left(V_{1 / 2}\right)$ of native and recombinant $\alpha_{1 \mathrm{H}}$ channels (Lu et al., 1994; Schrier et al., 2001; Wolfe et al., 2002). This regulation depends on active kinase (Lu et al., 1994; Barrett et al., 2000) and is not observed with human recombinant $\alpha_{1 \mathrm{G}}$ channels ( $\left.\mathrm{Ca}_{\mathrm{v}} 3.1\right)$ (Monteil et al., 2000) stably expressed in HEK293 cells (Wolfe et al., 2002). To test for the differential regulation of these two $\mathrm{Ca}_{\mathrm{v}} 3.0$ family members in a transient transfection paradigm, we cotransfected CaMKII with either the $\alpha_{1 \mathrm{H}}$ or the $\alpha_{1 \mathrm{G}}$ channel construct. Channel activity was measured using internal solutions that either promote $\left(1 \mu \mathrm{M}\right.$ free $\mathrm{Ca}^{2+} ; 2$ $\mu \mathrm{M}$ CaM) or impair (27 nM free $\mathrm{Ca}^{2+}$ ) CaMKII activation (Wolfe et al., 2002). $\mathrm{Ca}^{2+} / \mathrm{CaM}$ potentiates $\alpha_{1 \mathrm{H}}$ currents at potentials at which channel activation is incomplete $(-60$ to $0 \mathrm{mV})$ (Fig. $1 b)$. Neither currents recorded at maximally activating voltages $\left(V_{\text {test }}=+10 \mathrm{mV} ; V_{r}=-60 \mathrm{mV}\right)$ nor currents recorded from $\alpha_{1 \mathrm{G}}$ channels (Fig. 1b,e) are increased with CaMKII-activating internal solutions. The gating behavior of $\alpha_{1 \mathrm{H}}$ channels recorded with CaMKII-activating solutions is poorly fitted by a single squared Boltzmann function but is fitted significantly better $(p<0.05)$ by a double Boltzmann function that defines two channel populations. One population displays properties indistinguishable from channels recorded with impaired CaMKII activity [termed non-modulated (N-M)], whereas the other population [termed modulated (M)] displays a more hyperpolarized half-activation potential $\left(V_{1 / 2}\right)$ and an increased voltage sensitivity $(k)$ (Fig. $1 c$, inset). Concurrent analysis of the averaged data sets reveals that CaMKII activation modulates $\alpha_{1 \mathrm{H}}$ but not $\alpha_{1 \mathrm{G}}$ channels, inducing $\mathrm{a}-14.3 \pm 1.6 \mathrm{mV}(p<0.05)$ shift in the half-activation potential and an $\Delta-4.5 \pm 1.4 \mathrm{mV} / e$-fold $(p<0.05)$ increase in the voltage sensitivity of gating, as indicated by the reduction in slope factor $(k)$. A concomitant change in the midpoint and the apparent steepness of gating suggests that CaMKII may change the work required to open the channel, possibly by reducing the electrostatic surface potential sensed by the voltage-sensing module (Hille, 2001). On average, CaMKII modulates $45 \pm 9 \%$ of the $\alpha_{1 \mathrm{H}}$ channel population; however, in any given cell, modulation can be near complete or remain submaximal. An additional analysis of the regulation of $\alpha_{1 \mathrm{H}}$ channels shows that the CaMKIImodulated channel population in individual cells may be as large as $99 \%$ or as small as $21 \%$ of the total channel population ( $46 \pm$ $5 \%)$. We interpret this variability as a byproduct of transient transfection because the expression of GFP, one cotransfectant, is also 
a

$H-C a_{v} 3.2 \rho \int U^{m}$

b
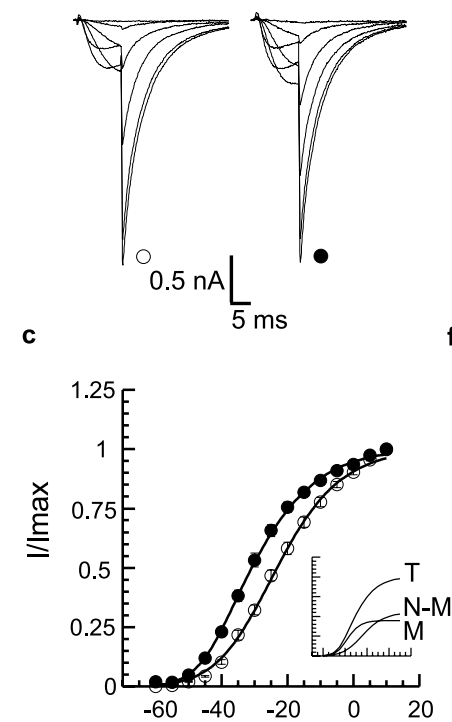

Membrane Potential $(\mathrm{mV})$ d

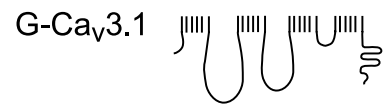

e
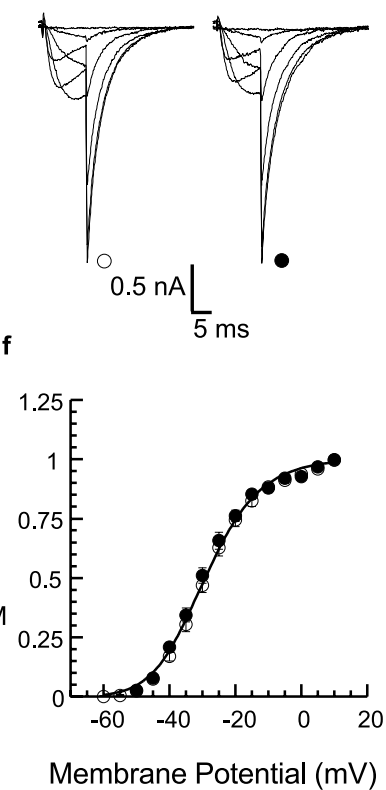

Figure 1. Effect of CaMKII activity on the voltage dependence of activation of T-type $\mathrm{Ca}^{2+}$ channels. $a, d$, Schematic representation of $\alpha_{1 \mathrm{H}}\left(\mathrm{Ca}_{\mathrm{v}} 3.2\right)$ and $\alpha_{1 \mathrm{G}}\left(\mathrm{Ca}_{\mathrm{v}} 3.1\right)$ channels. $b, e$, Whole-cell current traces recorded from $\alpha_{1 \mathrm{H}}(b)$ or $\alpha_{1 \mathrm{G}}(e)$ channels transiently expressed with CaMKII in HEK293 cells. Sample currents at $V_{\text {test }}=-55,-45,-35,-25,-10$, and $+10 \mathrm{mV}$ recorded with intracellular free $\mathrm{Ca}^{2+}$ fixed at $27 \mathrm{~nm} \mathrm{Ca}^{2+}$ (open symbols) to prevent CaMKII activation or $1 \mu \mathrm{M} \mathrm{Ca}{ }^{2+}$ plus $2 \mu \mathrm{M}$ CaM (filled symbols). Currents were normalized $\left(I_{\max }=2.5\right.$ $\mathrm{nA}$ ) to illustrate differences at hyperpolarized $V_{m}$ between channel subtypes recorded with CaMKIl activating solutions. $c$, $f$, Relative conductance (normalized tail current amplitudes, $I / I_{\text {max }}$ ) plotted (means $\pm S E M$ ) versus $V_{t}$. Data sets were fitted to squared Boltzmann functions; single functions provided good fits to low $\mathrm{Ca}^{2+}$ data (open symbols) for $\alpha_{1 \mathrm{H}}(\mathrm{c})\left[\mathrm{V}_{1 / 2}=\right.$ $-23.2 \pm 0.3 \mathrm{mV} ; k=10.9 \pm 0.4 \mathrm{mV} / e$-fold change; $n=17(27 \mathrm{~nm})]$ and to both low- and high-Ca ${ }^{2+}$ data for $\alpha_{1 \mathrm{G}}$ channels $(f)\left[V_{1 / 2}=-29.2 \pm 0.6 \mathrm{mV} ; k=9.4 \pm 0.4 \mathrm{mV} / \mathrm{e}\right.$-fold change; $n=16(27 \mathrm{~nm})$ and $\left.11\left(1 \mu \mathrm{M} \mathrm{Ca}{ }^{2+}\right)\right]$. Fitting to the sum of two functions was significantly better $(p<0.05)$ for the high-Ca ${ }^{2+}$ data for $\alpha_{1 \mathrm{H}}$. Inset shows the contributions of the two components fitted to the high- $\mathrm{Ca}^{2+} \alpha_{1 \mathrm{H}}$ data set (T); one component is identical to the low-C $\mathrm{a}^{2+}$ fit and is designated non-modulated (N-M), whereas the second modulated component $(M)$ activates at more hyperpolarized voltages $\left[M: V_{1 / 2}=-37.5 \pm 0.3 \mathrm{mV} ; k=6.4 \pm\right.$ $1.5 \mathrm{mV} / \mathrm{e}$-fold change; $n=15\left(1 \mu \mathrm{m}\left(\mathrm{a}^{2+}\right)\right]$.

variable. Nonetheless, the regulation of $\alpha_{1 \mathrm{H}}$ but not $\alpha_{1 \mathrm{G}}$ channels in transient transfection suggests that structural determinants in the channel protein may underlie CaMKII-induced regulation.

To determine the molecular basis for this regulation, we generated chimeric channel constructs from wild-type $\alpha_{1 \mathrm{H}}\left(\mathrm{Ca}_{\mathrm{v}} 3.2\right)$ and $\alpha_{1 \mathrm{G}}\left(\mathrm{Ca}_{\mathrm{v}} 3.1\right)$ channels. Replacement of the $\mathrm{H}_{\mathrm{II}-\mathrm{III}}$ linker with the $\mathrm{G}_{\mathrm{II}-\mathrm{III}}$ linker abolishes CaMKII-dependent regulation (Fig. $2 a-c)\left[\mathrm{H} / \mathrm{G}_{\text {II-III linker }}: V_{1 / 2}=-22.4 \pm 0.3 \mathrm{mV}, k=11.4 \pm 0.5 \mathrm{mV}\right.$; $n=15(27 \mathrm{nM})$ and $\left.11\left(1 \mu \mathrm{M} \mathrm{Ca}^{2+}\right)\right]$, suggesting that the determinants for the regulation of activation gating by CaMKII are located in the $\mathrm{H}_{\mathrm{II}-\mathrm{III}}$ linker. Despite the absence of regulation, other channel properties remain unchanged. Neither the voltage dependency of inactivation $(-65 \pm 0.2 \mathrm{mV})$ nor the $\tau$ of deactivation $(3.9 \pm 0.3 \mathrm{msec}$ at $-60 \mathrm{mV})$ of the $\mathrm{H} / \mathrm{G}_{\mathrm{II}-\mathrm{III}}$ linker chimera differs from that of $\alpha_{1 \mathrm{H}}$ wild-type channels $(-64.5 \pm 0.2 \mathrm{mV}$, $4.2 \pm 0.5$ msec; NS).

On the basis of the previous studies, we predicted that the $\mathrm{H}_{\mathrm{II}-\mathrm{III}}$ linker, when transferred to the $\alpha_{1 \mathrm{G}}$ backbone, would result a

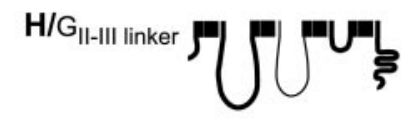

d

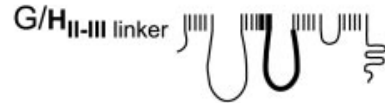

b

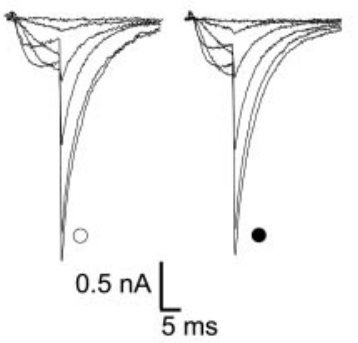

e
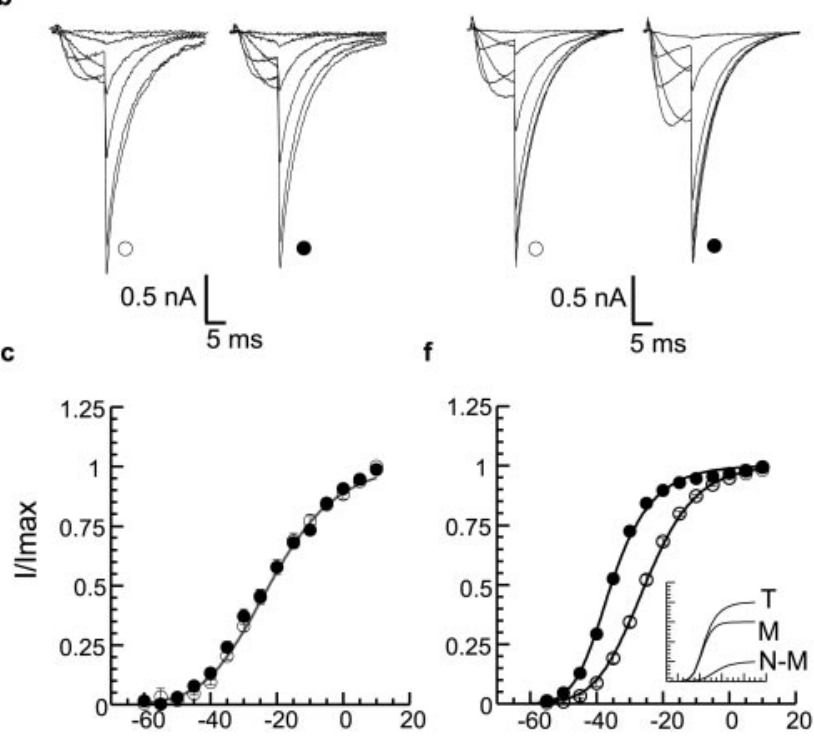

Membrane Potential $(\mathrm{mV})$

Figure 2. The II-III cytoplasmic linker of $\alpha_{1 \mathrm{H}}$ channels confers modulation in cells coexpressing CaMKII. $a, d$, Schematic representation of channel chimeras in which the II-III linker plus a single transmembrane helix is swapped. $b, e$, Sample currents at $V_{t}=-55,-45,-35$, $-25,-10$, and $+10 \mathrm{mV}$ recorded with solutions that impair (open symbols) or promote (filled symbols) CaMKII activation as presented in Figure $1, b$ and $e . c, f$, Normalized tail current amplitudes $\left(I / I_{\max }\right)$ plotted (means $\pm \mathrm{SEM}$ ) versus $V_{t}$. Single squared Boltzman functions provided good fits for both low- and high- $\mathrm{Ca}^{2+}$ data for $\mathrm{H} / \mathrm{G}_{\|-\| \| \text {linker }}(c)\left[V_{1 / 2}=-22.4 \pm 0.3\right.$ $\mathrm{mV} ; k=11.4 \pm 0.5 \mathrm{mV} ; n=15(27 \mathrm{~nm})$ and $\left.11\left(1 \mu \mathrm{m} \mathrm{Ca}{ }^{2+}\right)\right]$ and low-Ca ${ }^{2+}$ data (open symbols) for $\mathrm{G} / \mathrm{H}_{\|-I I I ~ l i n k e r}$. High Ca $\mathrm{C}^{2+}$ data for $\mathrm{G} / \mathrm{H}_{\|- \text {III linker }}$ fitted significantly better $(p<$

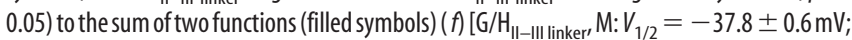
$\left.k=5.3 \pm 0.6 \mathrm{mV} ; n=17\left(1 \mu \mathrm{M} \mathrm{Ca}^{2+}\right)\right]$. Inset shows the fitted contribution of modulated (M) and non-modulated (N-M) channels to the voltage dependence of activation during CaMKII simulation (T). T, Sum of both fitted components for high $\mathrm{Ca}^{2+}$ data.

in a gain of regulation and tested for CaMKII-dependent regulation of this $\mathrm{G} / \mathrm{H}_{\text {II-III linker }}$ chimera. CaMKII activity shifts the half-activation potential of this chimera by $-9.4 \pm 0.4 \mathrm{mV}(p<$ 0.05 ) and also increases the voltage sensitivity by $\Delta-3.3 \pm 0.6$ $\mathrm{mV} / e$-fold change $(p<0.05)$. On average, $75 \pm 11 \%$ of the $\mathrm{G}$ chimeric channel population is modulated, displaying a halfactivation potential that is nearly identical to that recorded for CaMKII-modulated $\alpha_{1 \mathrm{H}}$ wild-type channels [G/H $\mathrm{H}_{\mathrm{II}-\mathrm{III}}$ linker: $\mathrm{M}$, $\left.V_{1 / 2}=-37.8 \pm 0.6 \mathrm{mV}, k=5.3 \pm 0.6 \mathrm{mV}, n=17\left(1 \mu \mathrm{M} \mathrm{Ca}^{2+}\right)\right]$. An additional analysis of the regulation of G-chimeric channels shows that the CaMKII-modulated channel population in individual cells may vary from 89 to $46 \%$ of the total channel population $(74 \pm 4 \%)$. This broad distribution differs but overlaps that observed for wild-type $\alpha_{1 \mathrm{H}}$ channels. The singular importance of the $\mathrm{H}_{\text {II-III }}$ linker to the CaMKII-dependent change in channel gating was corroborated by the construction of a second $\mathrm{G} / \mathrm{H}$ chimera that replaces a large segment of the $\alpha_{1 \mathrm{G}}$ channel from IIIS1 to the C terminus (residues 1294-2353), with the corresponding regions from $\alpha_{1 \mathrm{H}}$ channels. CaMKII-dependent regulation is not conferred to this $\mathrm{G} / \mathrm{H}_{\mathrm{C}}$ terminus chimera (Fig. $3 c$ ). On the basis of these findings, we conclude that residue(s) critical for CaMKII-dependent regulation are located in the $\mathrm{H}_{\text {II-III }}$ linker.

The $\alpha_{1 \mathrm{H}}$ channel is a large $259 \mathrm{kDa}$ membrane protein con- 
a

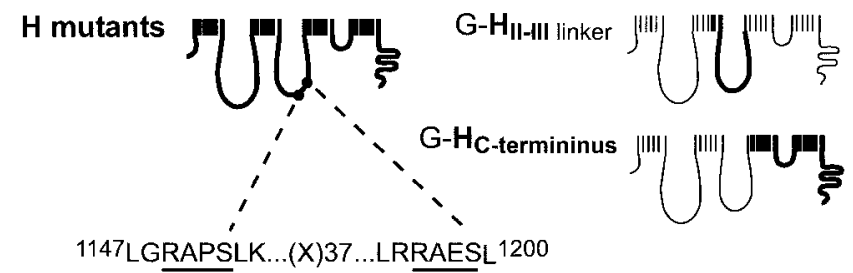

b
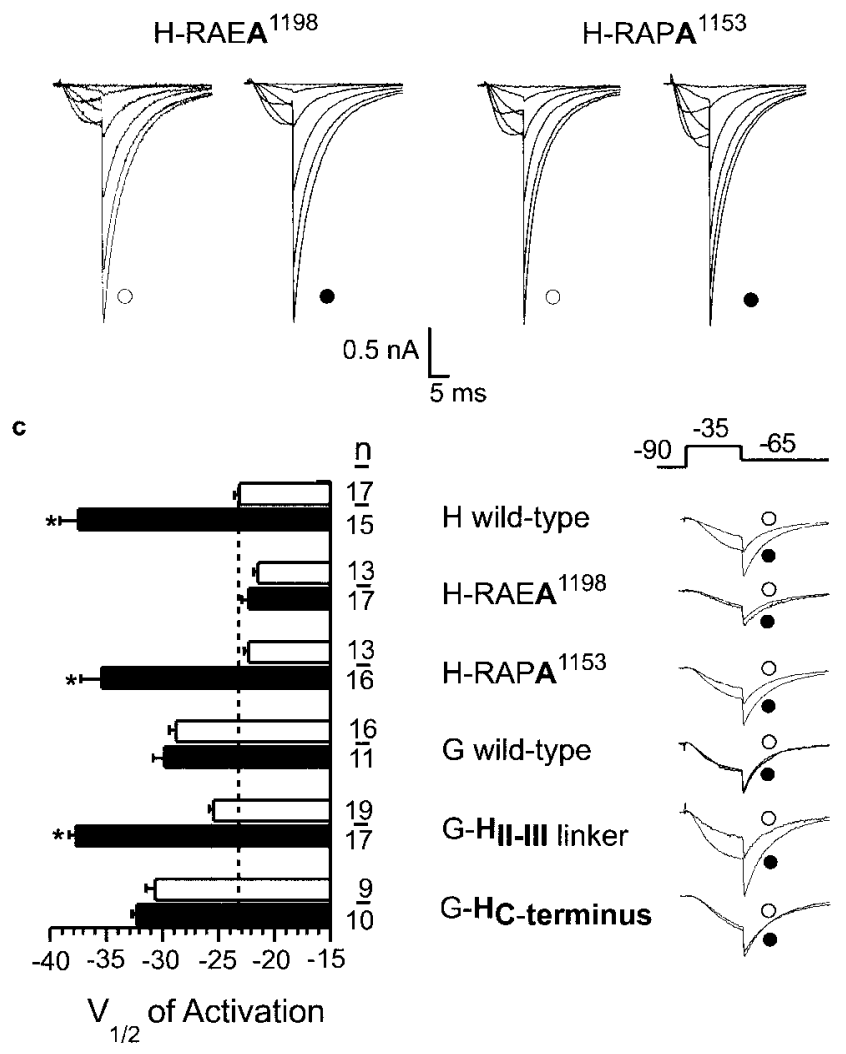

Figure 3. Effect of single point mutations on CaMKII-induced changes in channel gating. $a$, Schematic representation of $\alpha_{1 \mathrm{H}}$ chimeras in which CaMKII-consensus motifs on the $\mathrm{H}_{\|-\| I I}$ domain linker are mutated (RAPA ${ }^{1153}$ and RAEA ${ }^{1198}$ ), alone and in combination, and $\alpha_{16}$ chimeras with transferred $\alpha_{1 \mathrm{H}}$ domains. $b$, Sample currents at $V_{t}=-55,-45,-35,-25$, -10 , and $+10 \mathrm{mV}$ recorded with solutions that impair (open symbols) or promote (filled symbols) CaMKII activation as presented in Figure 1, $b$ and $e$. c, Fitted values for half-activation potential; open bars indicate low-Ca ${ }^{2+}$ fitted parameters (open bars), and filled bars indicate high-Ca ${ }^{2+}$ fitted parameters. Values are mean $\pm \mathrm{SE} ;{ }^{*} p<0.05 ; n$ indicates number of cells. Normalized current waveforms recorded at $V_{t}=-35 \mathrm{mV}\left(10 \mathrm{msec}, V_{\text {repolarization }}\right.$ of $\left.-60 \mathrm{mV}\right)$ with free $\mathrm{Ca}^{2+}$ fixed at $27 \mathrm{~nm} \mathrm{Ca}^{2+}$ (open symbols) or $1 \mu \mathrm{m} \mathrm{Ca}{ }^{2+}$ plus $2 \mu \mathrm{m}$ CaM (filled symbols).

taining 22 sites that conform to the minimal consensus sequence for CaMKII phosphorylation, RXXS/T (Soderling, 1996). We considered each site as a putative substrate for CaMKII using criteria established on the basis of the rank order of phosphorylation efficiency $\left(V_{\max } / K_{\mathrm{m}}\right)$ of a combinatorial peptide library (White et al., 1998). The ${ }^{1192}$ LRRAESL $^{1200}$ recognition motif, located in the 275 residue $\mathrm{H}_{\mathrm{II}-\mathrm{III}}$ linker, contains hydrophobic residues at -5 and +1 , a non-basic amino acid residue at -3 , and an alanine (Ala) at the -2 position, determinants that are known to enhance substrate recognition (White et al., 1998). Notably, no other motif in the channel protein has as many advantageous residues for substrate recognition, and this motif is not found in the $\alpha_{1 \mathrm{G}}$ sequence. To determine whether the LRRAES ${ }^{1198} \mathrm{~L}$ rec-

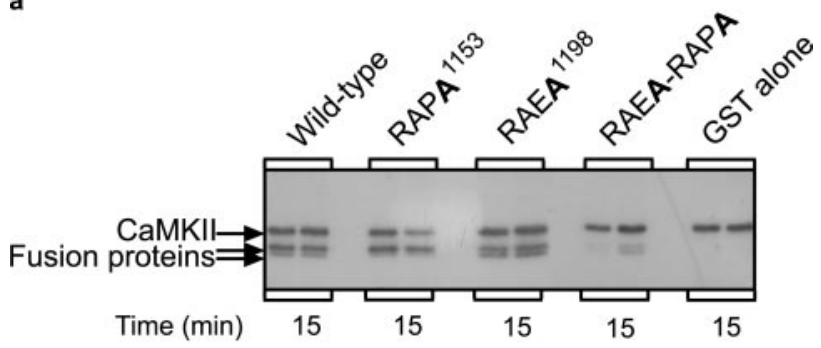

b

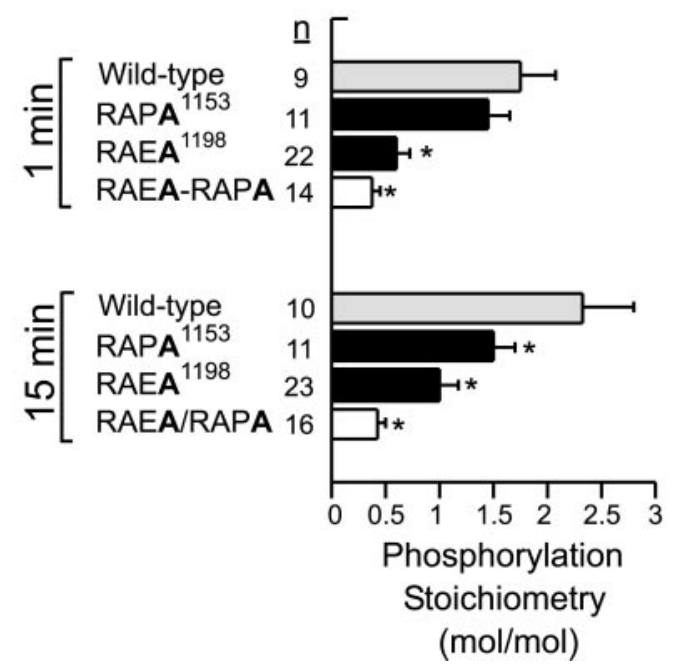

Figure 4. Phosphorylation of GST-domain II-III linker by CaMKII. $A$, GST fusion proteins containing residues 1039-1232 of domain linker II-III (wild-type or mutated at RAPA ${ }^{1153}$ and/or RAEA ${ }^{1198}$ ) were phosphorylated with purified recombinant CaMKIl $\gamma_{c}$ in the presence of [ $\gamma^{3}{ }^{32}$ P]ATP. Reactions were subjected to SDS-PAGE analysis. Representative autoradiograph showing phosphorylation state at $15 \min (n=2)$. Autophosphorylated CaMKII $\gamma_{c}$ resolves above the linker proteins. $b$, Analysis of phosphorylation stoichiometry of full-length linker protein $(47 \mathrm{kDa}$ ) at 1 and 15 min of incubation (mean $\pm \mathrm{SE}$ ). The apparent phosphorylation stoichiometry of the RAES ${ }^{1198}$ or RAPS ${ }^{1153}$ motifs is indicated by the difference in phosphorylation state between the single-mutated (hatched or stripped bars) and double-mutated (open bars) fusion proteins. Phosphate incorporation into mutant GST-linker fusion proteins were compared with wild-type using ANOVA with post hoc Dunnett's testing, in which significance was $p<0.05$.

ognition motif on the $\mathrm{H}_{\mathrm{II}-\mathrm{III}}$ linker is a site of CaMKII phosphorylation, we expressed GST fusion proteins containing $\sim 70 \%$ of the $\mathrm{H}_{\mathrm{II}-\mathrm{III}}$ linker that includes $\operatorname{Ser}^{1198}$ as well as Ser ${ }^{1153}$, a strong but less optimal substrate site $\left({ }^{1147}\right.$ LGRAPSLK $\left.^{1156}\right)$. Recombinant CaMKII (at $30 \mathrm{nM}$ ) phosphorylates the full-length wild-type linker protein $(47 \mathrm{kDa})$ as well as a proteolytic fragment $(44 \mathrm{kDa})$ lacking the RAES ${ }^{1198}$ motif that resolves as a lower band of a doublet on SDS-PAGE (Fig. 4a,b). The full-length wild-type linker protein is phosphorylated to a stoichiometry of $1.7 \mathrm{~mol}$ of $\mathrm{PO}_{4}$ incorporated per moles of protein at $1 \mathrm{~min}$, indicating that more than a single residue is phosphorylated, and reaches saturation at $15 \mathrm{~min}$, to attain a final stoichiometry of 2.3. Despite the presence of five CaMKII phosphorylation motifs on the $\mathrm{H}_{\text {II-III }}$ linker protein, the majority of incorporated phosphate at 1 and 15 min is distributed between Ser ${ }^{1198}$ and Ser ${ }^{1153}$. The combined mutation of these residues to Ala reduces phosphorylation by $\sim 80 \%$. At 1 min, Ser ${ }^{1198}$ is preferentially phosphorylated to full stoichiometry as determined by mutational analysis. In contrast, mutation of Ser ${ }^{1153}$, which is embedded in a less optimal substrate recognition motif, does not result in significant loss of $\mathrm{PO}_{4}$ 
incorporation at $1 \mathrm{~min}$. Longer incubation allows for the slower phosphorylation of the RAPS ${ }^{1153}$ motif and the recognition of other poorer substrates. Because rapid stoichiometric phosphorylation of a motif is a signature feature of a preferred kinase substrate, our findings suggested that the phosphorylation of Ser ${ }^{1198}$ on the $\mathrm{H}_{\text {II-III }}$ linker could be a critical event that mediates CaMKII-dependent changes in channel gating.

Finally, to test the functionality of the RAES ${ }^{1198}$ motif, we mutated Ser ${ }^{1198}$ in the full-length channel protein and assayed for CaMKII-dependent regulation of channel activity. Mutation of Ser ${ }^{1198}$ to Ala abrogates CaMKII-dependent modulation of $\alpha_{1 \mathrm{H}}$ channels (Fig. $3 c$ ). Neither the half-activation potential nor the voltage sensitivity differs from non-modulated wild-type $\alpha_{1 \mathrm{H}}$ channels $\left[V_{1 / 2}=-21.8 \pm 0.4 \mathrm{mV}, k=11.5 \pm 0.5 \mathrm{mV} ; n=17\right.$ (1 $\left.\mu \mathrm{M} \mathrm{Ca}^{2+}\right)$; NS]. In contrast, mutant $\alpha_{1 \mathrm{H}}$ channels harboring a $\mathrm{Ser}^{1153}$ to Ala mutation retain CaMKII-dependent modulation (M: $V_{1 / 2}=-35.4 \pm 1.9 \mathrm{mV} ; k=5.3 \pm 2.0 \mathrm{mV} / e$-fold change; $34 \pm 11 \% ; p<0.05)$.

Modification of protein function by phosphorylation can be the result of the accommodation of the bulk of the phosphate moiety (Busch et al., 2002) or the introduction of negative charge (Buchbinder et al., 1997). We mutated Ser ${ }^{1198}$ to glutamine (Gln) to test first for the possible importance of the loss of serine hydroxyl interactions during phosphate incorporation. Gln ${ }^{1198}$ failed to change either the half-activation potential or the voltage sensitivity of this mutant $\alpha_{1 \mathrm{H}}$ channel [ $V_{1 / 2}=-23.5 \pm 1.2 \mathrm{mV}$; $k=9.4 \pm 0.3 \mathrm{mV} ; n=10(27 \mathrm{nM})]$. Moreover, as observed previously with mutation of the RAES ${ }^{1198}$ motif, the loss of Ser ${ }^{1198}$ prevents regulation by CaMKII $\left[V_{1 / 2}=-25.2 \pm 0.7 \mathrm{mV}\right.$; $k=9.4 \pm 0.2 \mathrm{mV} ; n=11(1 \mu \mathrm{M})]$. In a similar manner, mutation of Ser ${ }^{1198}$ to glutamic acid (Glu) creates a channel with gating properties that mimic those of the Gln ${ }^{1198}$ mutant. Both the $V_{1 / 2}$ of activation and the voltage sensitivity of this mutant channel also remain unaltered in the absence and presence of CaMKII activation $\left[V_{1 / 2}=-24.8 \pm 0.8 \mathrm{mV}, k=9.8 \pm 0.4 \mathrm{mV}, n=12(27\right.$ $\left.\mathrm{nM}) ; V_{1 / 2}=-23.3 \pm 0.5 \mathrm{mV}, k=9.7 \pm 0.4 \mathrm{mV}, n=11 .,(1 \mu \mathrm{M})\right]$, suggesting that the monoanionic carboxylate group of Glu cannot replace the dianionic phosphate of phosphoserine in reproducing either the exact charge balance or the phosphopeptide positioning that is required to change channel gating (Buchbinder et al., 1997). Collectively, our mutagenesis studies provide support for our in vitro phosphorylation data and identify the key role played by Ser ${ }^{1198}$ in the observed changes in $\alpha_{1 \mathrm{H}}$ channel gating induced by CaMKII.

\section{Discussion}

The present data provide a molecular explanation for how CaMKII differentially regulates LVA $\mathrm{Ca}^{2+}$ channels. We described a remarkably simple way by which CaMKII changes $\alpha_{1 \mathrm{H}}$ activation gating. Here, we identify a single serine residue $\left(\operatorname{Ser}^{1198}\right.$ ) within the II-III cytoplasmic linker that is unique to $\alpha_{1 \mathrm{H}}$ channels, phosphorylated by CaMKII, and critical for channel regulation. This mechanism for $\mathrm{Ca}^{2+}$ channel regulation differs from that reported for $\alpha_{1 \mathrm{C}}\left(\mathrm{Ca}_{\mathrm{v}} 1.2\right)$ channels. Feedforward regulation (facilitation) of $\alpha_{1 \mathrm{C}}$ channels can be supported by a CaMKII-independent mechanism that requires CaM binding to an IQ motif (Zuhlke et al., 2000), a domain absent from the T-type $\mathrm{Ca}^{2+}$ channel family, and/or by a CaMKII-dependent mechanism that may require cytoskeletal intermediates (Yuan and Bers, 1994; Dzhura et al., 2000, 2002; Wu et al., 2001). However, the critical substrate(s) targeted by CaMKII remains undetermined. Our data support previous observations showing that the opening frequency of single $\alpha_{1 \mathrm{H}}$ channels in excised patches can be increased by membrane-associated CaMKII (Barrett et al., 2000). These studies showed that the participation of a cytosolic kinase cascade is not required for CaMKII-dependent regulation and implied the possibility of a direct modulation of $\alpha_{1 \mathrm{H}} \mathrm{Ca}^{2+}$ channels by CaMKII. Our data provide the first evidence for direct regulation of the pore-forming subunit of a voltagedependent $\mathrm{Ca}^{2+}$ channel by CaMKII.

The II-III cytoplasmic linker of the pore-forming channel subunit of other voltage-gated $\mathrm{Ca}^{2+}$ channels forms important structural associations with signaling effectors. In the $\mathrm{Ca}_{\mathrm{v}} 1 \mathrm{fam}-$ ily, the II-III linker of $\alpha_{1 S}$ couples the voltage sensor to the ryanodine-sensitive $\mathrm{Ca}^{2+}$ release channel (Tanabe et al., 1988, 1990), whereas in the $\mathrm{Ca}_{\mathrm{v}} 2$ family, the II-III linker facilitates efficient delivery of $\mathrm{Ca}^{2+}$ to sites of neurotransmitter release by binding SNARE (soluble $N$-ethylmaleimide-sensitive factor attached protein receptor) proteins that concomitantly modify inactivation gating (Sheng et al., 1994; Catterall, 2000; Jarvis and Zamponi, 2001). Our data highlight a role for the II-III linker of T-type $\mathrm{Ca}^{2+}$ channels and show that, in the $\mathrm{Ca}_{\mathrm{v}} 3$ family, the II-III linker is an important site for the control of activation gating. Recent studies from our laboratory indicate that the $\mathrm{H}_{\text {II-III }}$ linker also transduces current inhibition by directly binding G-protein $\beta_{2}$-containing $\beta \gamma$-dimers (Wolfe et al., 2003). Thus, in the $\mathrm{Ca}_{\mathrm{v}} 3$ family, the $\mathrm{H}_{\mathrm{II}-\mathrm{III}}$ linker may serve as a center for integrating effects of multiple stimuli.

Although mRNA transcripts encoding each of the T-type $\mathrm{Ca}^{2+}$ channel subtypes are widely expressed throughout the CNS and PNS, the pattern of expression of each channel gene is unique, albeit overlapping (Talley et al., 1999). $\alpha_{1 \mathrm{H}}$ mRNA is expressed at high levels in restricted regions of the hippocampus (pyramidal cell layers and granule layer of the dentate gyrus), cerebral cortex (a subset of layer V neocortical cells), and thalamus (reticular cells), as well as in sensory ganglia, dorsal horn neurons (external lamina), and the olfactory bulb. In contrast to other members of the $\mathrm{Ca}_{\mathrm{v}} 3$ $\mathrm{Ca}^{2+}$ channel family whose currents are blocked by $\mathrm{Ni}^{2+}$ with an $\mathrm{IC}_{50}$ that overlaps that for block of HVA Ca ${ }^{2+}$ channels, $\alpha_{1 \mathrm{H}}$ channels are inhibited by a $\mathrm{Ni}^{2+}$ concentration that is 20 - to 50 -fold lower ( $\mathrm{IC}_{50}$ of $10 \mu \mathrm{M}$ ) (Perez-Reyes, 2003).

The $\mathrm{Ni}^{2+}$ sensitivity of low-threshold, slowly deactivating $\mathrm{Ca}^{2+}$ channel currents has revealed the specific importance of the $\alpha_{1 \mathrm{H}}$ channel isoform in the following: hippocampal-neocortical dendritic low-threshold $\mathrm{Ca}^{2+}$ spike initiation (Markram and Sakmann, 1994; Magee and Johnston, 1995b), regenerative potential conduction, and somatic burst firing (Gillessen and Alzheimer, 1997; Larkum et al., 2001), as well as in both synaptic (lamina I projection neurons of the dorsal horn) and nonsynaptic (CA1 pyramidal neurons) forms of activity-dependent potentiation (Su et al., 2002; Ikeda et al., 2003). Given the broad distribution of $\alpha_{1 \mathrm{H}}$ channels and CaMKII in nervous tissue, the operation of the direct phosphorylation-dependent regulatory mechanism described here may be widespread, supporting the enhanced participation of $\alpha_{1 \mathrm{H}}$ channels in these diverse neuronal settings.

\section{References}

Barrett PQ, Lu HK, Colbran R, Czernik A, Pancrazio JJ (2000) Stimulation of unitary T-type $\mathrm{Ca}^{2+}$ channel currents by calmodulin-dependent protein kinase II. Am J Physiol 279:C1694-C1703.

Braun AP, Schulman H (1995) The multifunctional calcium/calmodulindependent protein kinase: from form to function. Annu Rev Physiol 57:417-445.

Buchbinder JL, Luong CB, Browner MF, Fletterick RJ (1997) Partial activation of muscle phosphorylase by replacement of serine 14 with acidic residues at the site of regulatory phosphorylation. Biochemistry 36:8039-8044.

Busch JL, Bessay EP, Francis SH, Corbin JD (2002) A conserved serine jux- 
taposed to the pseudosubstrate site of Type 1 cGMP-dependent protein inase contributes stronly to autoinhibition and lower cGMP affinity. J Biol Chem 277:34048-34054.

Catterall WA (2000) Structure and regulation of voltage-gated $\mathrm{Ca}^{2+}$ channels. Annu Rev Cell Dev Biol 16:521-555.

Cribbs LL, Lee JH, Yang J, Satin J, Zhang Y, Daud A, Barclay J, Williamson MP, Fox M, Rees M, Perez-Reyes E (1998) Cloning and characterization of $\alpha 1 \mathrm{H}$ from human heart, a member of the T-type $\mathrm{Ca}^{2+}$ channel gene family. Circ Res 83:103-109.

Cribbs LL, Gomora JC, Daud AN, Lee JH, Perez-Reyes E (2000) Molecular cloning and functional expression of $\mathrm{Ca}(\mathrm{v}) 3.1 \mathrm{c}$, a T-type calcium channel from human brain. FEBS Lett [Erratum (2000) 470:378] 466:54-58.

Destexhe A, Contreras D, Steriade M, Sejnowski TJ, Huguenard JR (1996) In vivo, in vitro, and computational analysis of dendritic calcium currents in thalamic reticular neurons. J Neurosci 16:169-185.

Dzhura I, Wu Y, Colbran RJ, Balser JR, Anderson ME (2000) Calmodulin kinase determines calcium-dependent facilitation of L-type calcium channels. Nat Cell Biol 2:173-177.

Dzhura I, Wu Y, Colbran RJ, Corbin JD, Balser JR, Anderson ME (2002) Cytoskeletal disrupting agents prevent calmodulin kinase, IQ domain, and voltage-dependent facilitation of L-type $\mathrm{Ca}^{2+}$ channels. J Physiol (Lond) 545 2:399-406.

Efron B, Tibshirani RJ (1993) An introduction to the bootstrap. New York: Chapman and Hall.

Eilers J, Konnerth A (1997) Dendritic signal integration. Curr Opin Neurobiol 7:385-390.

Fisher RE, Gray R, Johnston D (1990) Properties and distribution of single voltage-gated calcium channels in adult hippocampal neurons. J Neurophysiol 64:91-104.

Gillessen T, Alzheimer C (1997) Amplification of EPSPs by low $\mathrm{Ni}^{2+}$ - and amiloride-sensitive $\mathrm{Ca}^{2+}$ channels in apical dendrites of rat CA1 pyramidal neurons. J Neurophysiol 77:1639-1643.

Hausser M, Spruston N, Stuart GJ (2000) Diversity and dynamics of dendritic signaling. Science 290:739-744.

Hille B (2001) Gating: voltage sensing and inactivation. In: Ion channels of excitable membranes, Chap 19, Ed 3. Sunderland, MA: Sinauer.

Hudmon A, Schulman H (2002) Neuronal $\mathrm{Ca}^{2+} /$ calmodulin-dependent protein kinase II: the role of structure and autoregulation in cellular function. Annu Rev Biochem 71:473-510.

Huguenard JR (1996) Low-threshold calcium currents in central nervous system neurons. Annu Rev Physiol 58:329-348.

Huguenard JR, McCormick DA (1992) Simulation of the currents involved in rhythmic oscillations in thalamic relay neurons. J Neurophysiol 68:1373-1383.

Ikeda H, Heinke B, Ruscheweyh R, Sandkuhler J (2003) Synaptic plasticity in spinal lamina I projection neurons that mediate hyperalgesia. Science 299:1237-1240.

Jarvis SE, Zamponi GW (2001) Interactions between presynaptic $\mathrm{Ca}^{2+}$ channels, cytoplasmic messengers and proteins of the synaptic vesicle release complex. Trends Pharmacol Sci 22:519-525.

Johnson ML, Frasier SG (1985) Nonlinear least-squares analysis. In: Enzyme structure, Pt J (Hirs CHW, Timasheff SN, eds). London: Academic.

Kelly PT, McGuinness TL, Greengard P (1984) Evidence that the major postsynaptic density protein is a component of a $\mathrm{Ca}^{2+} /$ calmodulindependent protein kinase. Proc Natl Acad Sci USA 81:945-949.

Kennedy MB, Bennett MK, Erondu NE (1983) Biochemical and immunochemical evidence that the "major postsynaptic density protein" is a subunit of a calmodulin-dependent protein kinase. Proc Natl Acad Sci USA 80:7357-7361.

Larkum ME, Zhu JJ, Sakmann B (2001) Dendritic mechanisms underlying the coupling of the dendritic with the axonal action potential initiation zone of adult rat layer 5 pyramidal neurons. J Physiol (Lond) 533:447-466.

Lee JH, Daud AN, Cribbs LL, Lacerda AE, Pereverzev A, Klockner U, Schneider T, Perez-Reyes E (1999) Cloning and expression of a novel member of the low voltage-activated T-type calcium channel family. J Neurosci 19:1912-1921.

Liu XB, Jones EG (1996) Localization of alpha type II calcium calmodulindependent protein kinase at glutamatergic but not gamma-aminobutyric acid (GABAergic) synapses in thalamus and cerebral cortex. Proc Natl Acad Sci USA 93:7332-7336.

Lu HK, Fern RJ, Nee JJ, Barrett PQ (1994) $\mathrm{Ca}^{2+}$-dependent activation of T-type $\mathrm{Ca}^{2+}$ channels by calmodulin-dependent protein kinase II. Am J Physiol 267:F183-F189.
Magee JC, Johnston D (1995a) Characterization of single voltage-gated $\mathrm{Na}^{+}$and $\mathrm{Ca}^{2+}$ channels in apical dendrites of rat CA1 pyramidal neurons. J Physiol (Lond) 487:67-90.

Magee JC, Johnston D (1995b) Synaptic activation of voltage-gated channels in the dendrites of hippocampal pyramidal neurons. Science 268:301-304.

Markram H, Sakmann B (1994) Calcium transients in dendrites of neocortical neurons evoked by single subthreshold excitatory postsynaptic potentials via low-voltage-activated calcium channels. Proc Natl Acad Sci USA 91:5207-5211.

McCormick DA (1992) Neurotransmitter actions in the thalamus and cerebral cortex and their role in neuromodulation of thalamocortical activity. Prog Neurobiol 39:337-388.

Migliore M, Shepherd GM (2002) Emerging rules for the distributions of active dendritic conductances. Nat Rev Neurosci 3:362-370.

Monteil A, Chemin J, Bourinet E, Mennessier G, Lory P, Nargeot J (2000) Molecular and functional properties of the human alpha(1G) subunit that forms T-type calcium channels. J Biol Chem 275:6090-6100.

Perez-Reyes E (2003) Molecular physiology of low voltage-activated T-type calcium channels. Physiol Rev 83:117-161.

Perez-Reyes E, Cribbs LL, Daud A, Lacerda AE, Barclay J, Williamson MP, Fox M, Rees M, Lee JH (1998) Molecular characterization of a neuronal low-voltage-activated T-type calcium channel. Nature 391:896-900.

Schrier AD, Wang H, Talley EM, Perez-Reyes E, Barrett PQ (2001) $\alpha 1 \mathrm{H}$ T-type $\mathrm{Ca}^{2+}$ channel is the predominant subtype expressed in bovine and rat zona glomerulosa. Am J Physiol 280:C265-C272.

Shen K, Teruel MN, Subramanian K, Meyer T (1998) CaMKIIbeta functions as an F-actin targeting module that localizes CaMKIIalpha/beta heterooligomers to dendritic spines. Neuron 21:593-606.

Sheng ZH, Rettig J, Takahashi M, Catterall WA (1994) Identification of a syntaxin-binding site on N-type calcium channels. Neuron 13:1303-1313.

Soderling TR (1996) Structure and regulation of calcium/calmodulindependent protein kinases II and IV. Biochim Biophys Acta 1297:131-138.

Soderling TR, Derkach VA (2000) Postsynaptic protein phosphorylation and LTP. Trends Neurosci 23:75-80.

Straume M, Johnson M, eds (1992) Numerical computer methods. San Diego: Academic.

Su H, Sochivko D, Becker A, Chen J, Jiang Y, Yaari Y, Beck H (2002) Upregulation of a T-type $\mathrm{Ca}^{2+}$ channel causes a long-lasting modification of neuronal firing mode after status epilepticus. J Neurosci 22:3645-3655.

Talley EM, Cribbs LL, Lee JH, Daud A, Perez-Reyes E, Bayliss DA (1999) Differential distribution of three members of a gene family encoding low voltage-activated (T-type) calcium channels. J Neurosci 19:1895-1911.

Tanabe T, Beam KG, Powell JA, Numa S (1988) Restoration of excitationcontraction coupling and slow calcium current in dysgenic muscle by dihydropyridine receptor complementary DNA. Nature 336:134-139.

Tanabe T, Beam KG, Adams BA, Niidome T, Numa S (1990) Regions of the skeletal muscle dihydropyridine receptor critical for excitationcontraction coupling. Nature 346:567-569.

Thiagarajan TC, Piedras-Renteria ES, Tsien RW (2002) alpha- and betaCaMKII. Inverse regulation by neuronal activity and opposing effects on synaptic strength. Neuron 36:1103-1114.

White RR, Kwon YG, Taing M, Lawrence DS, Edelman AM (1998) Definition of optimal substrate recognition motifs of $\mathrm{Ca}^{2+}$-calmodulindependent protein kinases IV and II reveals shared and distinctive features. J Biol Chem 273:3166-3172.

Wolfe JT, Wang H, Perez-Reyes E, Barrett PQ (2002) Stimulation of recombinant $\mathrm{Ca}(\mathrm{v}) 3.2$, T-type, $\mathrm{Ca}^{2+}$ channel currents by CaMKII $\gamma \mathrm{C}$. J Physiol (Lond) 538:343-355.

Wolfe JT, Wang H, Howard J, Garrison JC, Barrett PQ (2003) T-type calcium channel regulation by specific G-protein $\beta \gamma$ subunits. Nature 424:209-213.

Wu Y, Dzhura I, Colbran RJ, Anderson ME (2001) Calmodulin kinase and a calmodulin-binding "IQ" domain facilitate L-type $\mathrm{Ca}^{2+}$ current in rabbit ventricular myocytes by a common mechanism. J Physiol (Lond) 535:679-687.

Yuan W, Bers DM (1994) Ca-dependent facilitation of cardiac Ca current is due to Ca-calmodulin-dependent protein kinase. Am J Physiol 267:H982-H993.

Zuhlke RD, Pitt GS, Tsien RW, Reuter H (2000) $\mathrm{Ca}^{2+}$-sensitive inactivation and facilitation of L-type $\mathrm{Ca}^{2+}$ channels both depend on specific amino acid residues in a consensus calmodulin-binding motif in the $\alpha 1 \mathrm{C}$ subunit. J Biol Chem 275:21121-21129. 